\title{
Matrine inhibits vascular smooth muscle cell proliferation by modulating the expression of cell cycle regulatory genes
}

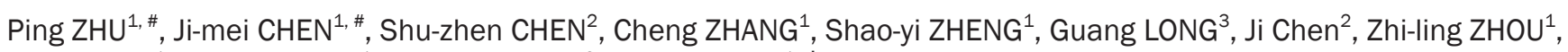
Rui-xin FAN ${ }^{1}$, Xiao-ping FAN $^{1}$, Yan-fang $\mathrm{CHEN}^{2}$, Jian ZHUANG ${ }^{1, *}$

${ }^{1}$ Department of Cardiovascular Surgery, Guangdong Cardiovascular Institute, Guangdong General Hospital, and Guangdong Academy of Medical Sciences, Guangzhou 510100, China; ${ }^{2}$ Department of Pharmacology \& Toxicology, Wright State University Boonshoft School of Medicine, Dayton, OH 45435, USA; ${ }^{3}$ Nanhua University School of Medicine, Hengyang 421001, China

Aim: To investigate the effect of matrine on proliferation of vascular smooth muscle cells (VSMCs) and elucidate the underlying mechanisms.

Methods: Rat aortic VSMCs were cultured in medium supplemented with $10 \%$ fetal bovine serum and treated with various concentrations $(0,5,10,15$, and $20 \mathrm{mg} / \mathrm{L})$ of matrine for $72 \mathrm{~h}$. VSMCs proliferation and cell cycle profiling were assessed using a methylene blue incorporation assay and flow cytometry, respectively. The underlying protein signaling mechanisms were determined using Western blot analysis of the expression levels of cell cycle regulatory genes, including p53, p21, p27, cyclin D1, cyclin E, cyclin-dependent kinase 2 and 4 (cdk2, cdk4), and phosphorylated Rb. The involvement of p21 and p27 pathways was further determined using small interfering RNA (siRNA) knockdown.

Results: Matrine inhibited VSMC proliferation in a dose-dependent manner by promoting $\mathrm{G}_{1}$ arrest. The $\mathrm{G}_{1}$ arrest was accompanied by up-regulation of p53 and p21 protein levels, and down-regulation of cyclin D1/cdk4, cyclin E/cdk2 and phosphorylated Rb protein levels. Matrine did not affect p27 expression. Furthermore, the anti-proliferative effect of matrine was abolished by silencing of p21, but not by silencing of $\mathrm{p} 27$.

Conclusion: Our data indicate that matrine has an inhibitory effect on VSMC proliferation via up-regulation of the p53/p21 signaling pathway and modulation of other cell cycle regulatory genes.

Keywords: matrine; vascular smooth muscle cells; proliferation; cell cycle; p21; p27; cyclin D1, cyclin E; cdk 2; cdk 4

Acta Pharmacologica Sinica (2010) 31: 1329-1335; doi: 10.1038/aps.2010.145; published online 13 Sep 2010

\section{Introduction}

Intimal hyperplasia following angioplasty and stenting remains a major obstacle limiting the success of clinical vascular interventions. It probably arises due to activation and tumor-like transformation of normally quiescent medial vascular smooth muscle cells (VSMCs). Transformed VSMCs migrate from the medium into the intima, where they proliferate and promote intimal hyperplasia ${ }^{[1,2]}$. Therefore, identification of new therapies and pharmacological targets aimed at reducing VSMCs proliferation is of great clinical significance.

Matrine $\left(\mathrm{C}_{15} \mathrm{H}_{24} \mathrm{~N}_{2} \mathrm{O}\right)$ is a major components of Radix Sopho-

\footnotetext{
\# The two authors contributed equally to this work.

* To whom correspondence should be addressed.

E-mail zhuangjianzggd@yahoo.cn

Received 2010-03-11 Accepted 2010-07-23
}

rae Flavescentis ${ }^{[3,4]}$. It has a wide range of pharmacological applications including anti-hepatitis ${ }^{[5]}$, anti-cancer ${ }^{[6]}$, and antiinflammatory properties, with no obvious toxicity or side effects. Matrine's anti-cancer effect has been observed in various cancer cells, including leukemia, cervical, gastric and lung cancers ${ }^{[7-10]}$. The anti-cancer properties of matrine may stem from inhibitory effects on cell proliferation, as well as induction of apoptosis, perhaps via modulation of apoptosis and proliferation regulating genes, such as p53, c-myc, E2F-1, Apaf-1, Rb, and Bcl-2 family members ${ }^{[11-13]}$.

Matrine has also been shown to affect the cardiovascular system, with demonstrated effects on hypotension and bradycardia ${ }^{[14]}$. Matrine promotes $\mathrm{G}_{1}$ cell cycle arrest and induces apoptosis in cardiac fibroblasts ${ }^{[4]}$. However, whether and how matrine affects VSMCs are poorly understood. The p53, p21, and p27 cell cycle regulating proteins regulate VSMC 
proliferation. Previous studies demonstrated that statins cause $\mathrm{G}_{1}$ arrest in VSMCs by increasing p27 expression and reducing cyclin E expression ${ }^{[15,16]}$. Alternatively, rapamycin inhibits VSMC proliferation by inducing a p21-mediated $\mathrm{G}_{1}$ arrest $^{[17]}$. Cyclin-dependent kinase 2 and 4 (cdk2 and cdk4) and their respective partners, cyclin $\mathrm{E}$ and cyclin $\mathrm{D}$, play pivotal roles in cell cycle progression ${ }^{[18]}$. Cyclin D1/cdk4 and cyclin E/ $\mathrm{cdk} 2$ mediate phosphorylation of retinoblastoma $(\mathrm{Rb})$ protein. Expression of cyclin D1 seems to be regulated by extracellular mitogens, while expression of cyclin $\mathrm{E}$ is controlled by autonomous mechanisms ${ }^{[19,20]}$. However, cyclin $\mathrm{E}$ is thought to promote $\mathrm{Rb}$ phosphorylation by cyclin D-cdk 4 complexes ${ }^{[21]}$. A study in cyclin E knockout mice demonstrates that it is essential for cell cycle re-entry ${ }^{[22]}$.

The aim of this study was to determine the effect of matrine on VSMC proliferation and cell cycle progression by modulating the expression of cell cycle regulatory genes.

\section{Materials and methods Materials}

Matrine (purity, >99\%) was obtained from the National Institute for the Control of Pharmaceutical and Biological Products (Beijing, China). Rapamycin and all antibodies were purchased from Sigma (St Louis, MO, USA). Dulbecco's modified Eagle's medium (DMEM), heat-inactivated fetal bovine serum (FBS) and penicillin/streptomycin were obtained from Gibco Life Technologies Inc (Rockville, MD, USA). The siRNA construction kit was purchased from Ambion (Cambridgeshire, UK). The p27 siRNA was purchased from Santa Cruz Biotechnology Inc (Paso Robles, CA, USA). All experimental procedures were approved by the Guangdong Academy of Medical Sciences Research Committee and were in accordance with National Institutes of Health guidelines.

\section{Cell culture}

Rat aortic VSMCs were isolated from the intimal-medial layer of the aorta as described previously ${ }^{[23,24]}$. Briefly, thoracic aortas from 2-month-old male Sprague-Dawley rats were used for explant cultures. Explants were cultured in DMEM supplemented with $10 \%(v / v)$ FBS and $1 \%(v / v)$ penicillin/streptomycin at $37{ }^{\circ} \mathrm{C}$ in $5 \% \mathrm{CO}_{2}$. VSMCs purity was evaluated by morphological analysis and immunocytochemical staining with a monoclonal antibody against smooth muscle a-actin. Prior to treatment, cells were grown to $\sim 75 \%$ confluence and incubated in a serum-free medium for $24 \mathrm{~h}$ to induce quiescence. VSMCs from passages 4-6 were used in this study.

Rapamycin was used as a positive control because it is known to exert an antiproliferative effect on VSMCs, and its effects on the expression of cell cycle genes are well documented $^{[17,24-26]}$.

\section{Cell proliferation analysis}

VSMC proliferation was assessed by using methylene blue incorporation assay in 96-well microculture plates, as previously described $^{[27]}$. Briefly, VSMC monolayer cells were suspended in $0.02 \%$ EDTA/ $0.02 \%$ trypsin, calcium- and magnesium-free phosphate-buffered saline (PBS), spun down and resuspended in DMEM medium. Cells $\left(6 \times 10^{3} / 100 \mu \mathrm{L} /\right.$ well) were transferred into 96-well culture plates and cultured in DMEM medium supplemented with $10 \%$ FBS and then treated with various concentrations $(0,5,10,15$, and $20 \mathrm{mg} /$ $\mathrm{L})$ of matrine or rapamycin $(100 \mathrm{ng} / \mathrm{L}$, with rapamycin acting as positive control) for $72 \mathrm{~h}$. Cells were then fixed in $10 \%$ formaldehyde saline for $30 \mathrm{~min}$, and then incubated with $1 \%$ $(w / v)$ methylene blue in $0.01 \mathrm{~mol} / \mathrm{L}$ borate buffer $(\mathrm{pH} 8.5)$ for $30 \mathrm{~min}$. The remaining dye was washed off by serially dipping the plate into each of four tanks of $0.01 \mathrm{~mol} / \mathrm{L}$ borate buffer $(\mathrm{pH} 8.5)$. To elute the dye, $100 \mu \mathrm{L}$ of $1: 1(v / v)$ ethanol and $0.1 \mathrm{~mol} / \mathrm{L} \mathrm{HCl}$ were added to each well. The plates were then gently shaken and absorbance measurements at $650 \mathrm{~nm}\left(\mathrm{~A}_{650}\right)$ were collected for each well using a microplate photometer (Flow Laboratories Ltd, Irvine, Scotland). The photometer was blanked on the first column of control wells containing elution solvent alone. The percent changes in $\mathrm{A}_{650}$ were calculated and compared.

\section{Cell cycle analysis}

VSMCs were cultured and treated as described for proliferation assays. Following $72 \mathrm{~h}$ of treatment with matrine $(0,5,10$, 15 , and $20 \mathrm{mg} / \mathrm{L})$ or rapamycin $(100 \mathrm{ng} / \mathrm{L}$, as positive control), VSMCs were harvested with $0.02 \%$ EDTA/ $0.02 \%$ trypsin in calcium- and magnesium-free PBS, fixed in $70 \%$ ethanol for $1 \mathrm{~h}$, and treated with $100 \mu \mathrm{g} / \mathrm{mL}$ RNase A for $1 \mathrm{~h}$ at $37^{\circ} \mathrm{C}$. Then, cells $\left(5 \times 10^{5}\right.$ cells $\left./ 100 \mu \mathrm{L}\right)$ were stained with $25 \mu \mathrm{g} / \mathrm{mL}$ propidium iodide (PI) (Jingmei Biotech Co Ltd, Shenzhen, China) for $15 \mathrm{~min}$ at room temperature in the dark. Cell cycle distribution was analyzed by flow cytometry (FACS Calibur system, Becton\& Dickinson; San Jose, CA, USA) as previously described ${ }^{[28]}$. The number of cells in $G_{0} / G_{1}, S$, and $G_{2} / M$ phases was expressed as a percentage of total cells.

\section{Western blotting}

VSMCs that were cultured and treated with matrine as described above were used for Western blot analysis. Protein concentrations in the cell lysates were determined using a Bicinchoninic acid kit (Sigma). Proteins (30 $\mu \mathrm{g} /$ lane) were fractionated via $10 \%-12 \%(w / v)$ sodium dodecyl sulfate polyacrylamide gel electrophoresis (SDS-PAGE) and then transferred to polyvinylidene difluoride membranes (Bio-Rad Laboratories, Milan, Italy). The membranes were incubated overnight with primary antibodies (1:400 dilutions) for p53, p21, p27, cyclin D1, cyclin E, cdk2, cdk4, phosphorylated Rb, or anti- $\beta$-actin (1:1000 dilutions) for $1 \mathrm{~h}$. After washing with PBS containing $0.1 \%(v / v)$ Tween 20 , membranes were incubated with corresponding horseradish peroxidase conjugated secondary antibodies (1:1000 dilutions) for $1 \mathrm{~h}$, followed by exposure using enhanced chemiluminescence detection reagents (Roche Applied Science). Western blots were scanned and quantified using Quantity One software (Bio-Rad Laboratories). Protein levels were normalized relative to $\beta$-actin protein levels. Fold changes in protein levels were calculated and compared. 


\section{Transfection of $\mathrm{p} 21$ or $\mathrm{p} 27$ siRNA}

The siRNA for p21 (5'-GACCAUGUGGACCUGUCAC-3', antisense) was synthesized in vitro using the siRNA construction kit (Ambion, Cambridgeshire, UK) as previously reported ${ }^{[29]}$. Cells were plated at $60 \%$ confluency in six-well culture dishes 1 day prior to transfection. Immediately before transfection, cells were washed with PBS. Transfection was carried out using Genesilencer (PeqLab, Germany) according to the manufacturer's protocol. Briefly, 1000 ng of p21 or p27 target siRNA (Santa Cruz Biotechnology Inc, Paso Robles, USA) was diluted in a mixture of $25 \mu \mathrm{L}$ siRNA diluent and $15 \mu \mathrm{L}$ serumfree medium, and incubated for $5 \mathrm{~min}$ at room temperature. The siRNA solution was added to the Genesilencer and incubated for $5 \mathrm{~min}$ at room temperature before the entire solution was added to the cells. Twelve hrs after transfection, the cells were treated with matrine $(20 \mathrm{mg} / \mathrm{L})$ for $72 \mathrm{~h}$, and subjected to proliferation and western blot analyses, as described above.

\section{Statistical analysis}

The data were expressed as means \pm standard error of the mean (SEM) and subjected to statistical analysis using the software package SPSS 12.0 (SPSS Inc, Chicago, IL). One-way or two-way ANOVA was used for the analysis of variance and followed by the Spearman method to evaluate differences between groups. Differences were significant when $P<0.05$.

\section{Results}

\section{VSMCs were isolated from rat aortas}

Rat aortic VSMCs were isolated from aortic explants. The purity of VSMCs was assessed via immunostaining for smooth muscle a-actin (Figure 1A). Primary cultures consisting of $<95 \%$ VSMCs were discarded. Cellular viability was determined by trypan blue exclusion.

\section{Matrine inhibits VSMCs proliferation}

VSMCs proliferation was assessed using the colorimetric assay of methylene blue incorporation. We found that treatment with matrine inhibited VSMCs proliferation in a concentration-dependent manner (Figure 1B). Cell number was significantly lower in $10 \mathrm{mg} / \mathrm{L}$ of matrine, and was further decreased in $20 \mathrm{mg} / \mathrm{L}$ of matrine, similar to the proliferation inhibition observed following treatment with $100 \mathrm{ng} / \mathrm{L}$ of rapamycin. The variation within a plate was $3.5 \%$. The coefficient of variation between plates was $2.5 \%$.

\section{Matrine treatment leads to $\mathrm{G}_{1}$ arrest in VSMCs}

Cultured VSMCs were treated with matrine and PI stained for flow-cytometric analysis. The DNA content histograms revealed that matrine led to a $G_{1}$ phase halt in a dose- dependent manner (Figure 2A). Figure 2B summarizes the effect of matrine on the proportion of $G_{1}$ phase VSMCs at different concentrations. After treatment with $20 \mathrm{mg} / \mathrm{L}$ of matrine, the proportion of $\mathrm{G}_{1}$ phase cells was increased from $84.8 \% \pm 1.3 \%$ to $96.6 \% \pm 0.8 \%(n=5 /$ group,$P<0.05)$ and the proportion of $S$ phase cells decreased from $9.9 \% \pm 1.2 \%$ to $1.5 \% \pm 0.9 \% \quad(n=5 /$ group, $P<0.05)$. Treatment with matrine at a $20 \mathrm{mg} / \mathrm{L}$ conce-
A

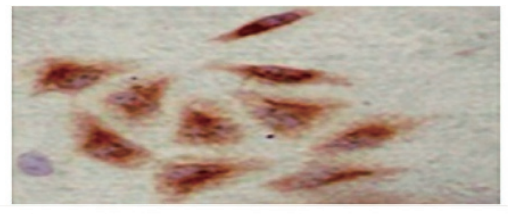

B

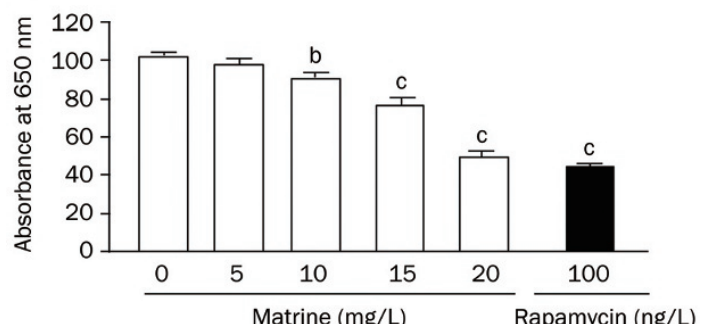

Figure 1. (A) Characterization of cultured rat aortic VSMCs (3th passage, $400 \times$ ) by immunohistochemical staining with anti- $\alpha$-smooth muscle actin monoclonal antibody; (B) Effect of matrine on VSMC proliferation in microwell plates. VSMCs were treated with various concentrations of matrine $(0,5,10,15$, and $20 \mathrm{mg} / \mathrm{L})$ for $72 \mathrm{~h}$. Rapamycin (100 ng/L) was as a positive control. Cell growth was determined by colorimetric assay of methylene blue incorporation. The changes in percentage of control $(0$ $\mathrm{mg} / \mathrm{L}$ matrine) were calculated. Data are expressed as mean \pm SEM. $n=5 /$ group, One-way ANOVA. ${ }^{b} P<0.05,{ }^{c} P<0.01$ vs control.

tration induced $G_{1}$ cell arrest similar to that induced by treatment of $100 \mathrm{ng} / \mathrm{L}$ rapamycin.

Matrine upregulates p53 and p21 protein levels, but does not affect p27 protein level

To explore the mechanism by which matrine inhibites VSMCs proliferation, we examined protein levels of p53, p21, and p27 using Western blot analysis. As seen in Figure 3, matrine led to a dose-dependent increase in the expression of p53 and p21. At $20 \mathrm{mg} / \mathrm{L}$, matrine induced increases in p53 and p21 proteins similar to those observed following $100 \mathrm{ng} / \mathrm{L}$ rapamycin treatment. Unlike rapamecin, matrine (5-20 mg/L) did not significantly alter the level of p27 protein in VSMCs.

Inhibition of p21, but not p27, rescued matrine-induced proliferation in VSMCs

To determine the roles of p21 and p27 in mediating the antiproliferation effect of matrine on VSMCs, we transfected the cells with p21 or p27 siRNA $12 \mathrm{~h}$ before the cells were treated with matrine $(20 \mathrm{mg} / \mathrm{L})$. As seen in Figure 4A, both p21 and p27 siRNAs specifically down-regulated target gene expression in VSMCs by $65 \%-75 \%$. Additionally, siRNA-mediated down-regulation of p21 abolished the inhibitory effect of matrine on VSMC proliferation. Silencing p27 had no significant influence on the inhibitory effect of matrine (Figure 4B).

Effect of matrine on protein expression levels of cyclin D1, cyclin E, cdk2, cd4, and phosphorylated Rb

To further investigate the mechanism by which matrine leads to $\mathrm{G}_{1}$ arrest in VSMCs, we examined levels of cell cycle regu- 

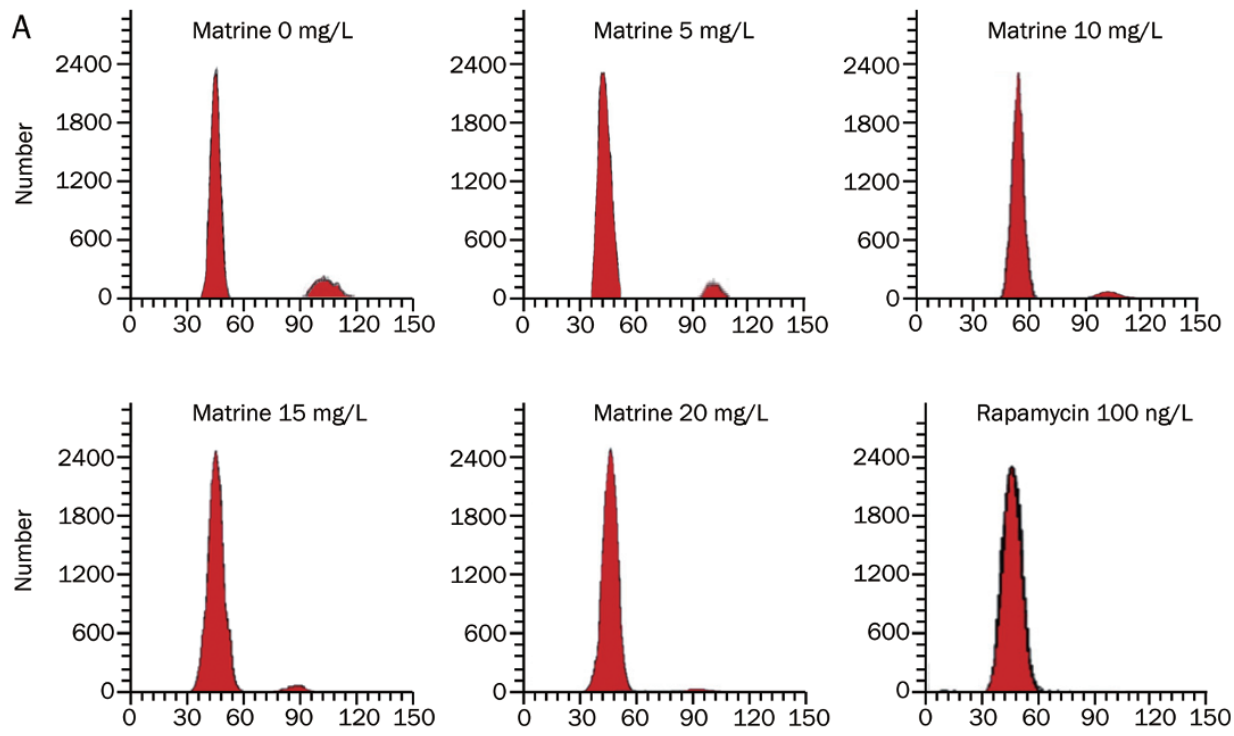

Figure 2. Effect of matrine on cell cycle progress in cultured VSMCs. VSMCs were treated with various doses of matrine $(0,5$, 10,15 , and $20 \mathrm{mg} / \mathrm{L}$ ) for $72 \mathrm{~h}$. Rapamycin (100 ng/L) was as a positive control. Cell cycle progress was determined by flow cytometry. Panel A shows representative histograms of flow cytometric analysis; Panel $B$ is the summarized data of $G_{1}$ phase VSMCs after treatments. The percentage of $G_{1}$ phase cells in total events was calculated. Data are expressed as mean \pm SEM. $n=5 /$ group, One-way ANOVA. ${ }^{\mathrm{b}} P<0.05,{ }^{\mathrm{c}} P<0.01$ vs treatment control $(0$ $\mathrm{mg} / \mathrm{L}$ matrine).

latory proteins, including cyclin D1, cyclin E, cdk2, cd4, and phosphorylated $\mathrm{Rb}$. As seen in Figure 5, matrine decreased levels of cyclin D1, cyclin E, cdk2, and cdk4 and phosphorylated $\mathrm{Rb}$ in a dose-dependent fashion. Matrine $(20 \mathrm{mg} / \mathrm{L})$ treatment induced increases in protein levels similar to those observed following rapamycin $(100 \mathrm{ng} / \mathrm{L})$ treatment.

\section{Discussion}

To investigate the role of matrine in VSMC proliferation and determine underlying mechanisms, we studied the effect of matrine on 10\% FBS-stimulated VSMC proliferation, cell cycle progression, and expression of cell cycle regulatory genes. We found that matrine inhibited VSMC proliferation and reduced cell cycle progression by promoting a G1 phase block. These effects are accompanied by increased levels of p53 and p21, and down-regulation of cyclin D1, cyclin E, cdk 2, cdk4, and phosphorylated $\mathrm{Rb}$ protein.

VSMCs cultured in 10\% FBS medium are commonly used as an in vitro model to study neointimal proliferation. Under this culture condition, VSMCs undergo tumor-like transformation and proliferation. In previous studies ${ }^{[7-11]}$, several tumor cell lines, such as leukemia K562 and hepatocellular carcinoma H22 cells, were incubated with matrine (100-900 mg/L) for 48 $\mathrm{h}$ to 4 days. In these cell lines, matrine was able to inhibit cell growth and increase p53 and p21 mRNA expression levels.

We treated cells with lower doses (10-20 mg/L) of matrine because we reasoned that VSMCs would not be as malignant as tumor cells and would therefore be more sensitive to treatment. As we expected, our results show that matrine inhibits the proliferation in transformed VSMCs at these relatively low doses. We also found that matrine elicits its anti-proliferative effect on VSMCs by inducing $\mathrm{G}_{1}$ phase arrest. In this study, rapamycin was used as a positive control because it has demonstrated anti-proliferative properties in a variety of cell types. Rapamycin inhibits a multifunctional serine-threonine kinase, the mammalian target of rapamycin (mTOR) ${ }^{[24,25]}$. Furthermore, our data showed that matrine $(20 \mathrm{mg} / \mathrm{L})$ treatment was similar to rapamycin $(100 \mathrm{ng} / \mathrm{L})$ treatment because both inhibited VSMC proliferation and induced $\mathrm{G}_{1}$ arrest ${ }^{[17]}$. These observations demonstrate that matrine is effective in inhibiting VSMC proliferation.

Previous studies demonstrated that statins promote $\mathrm{G}_{1}$ arrest in VSMCs by increasing cellular p27 levels and reducing cyclin E expression ${ }^{[15,16]}$. In contrast, rapamycin inhibits VSMC proliferation by halting cells in $\mathrm{G}_{1}$ by up-regulation of p21 protein ${ }^{[17]}$. To explore the mechanism by which matrine inhibits proliferation and causes $\mathrm{G}_{1}$ arrest in VSMCs, we first examined protein levels of p53, p21, and p27 in VSMCs following treatment with various concentrations of matrine $(0-20 \mathrm{mg} / \mathrm{L})$. Then, we determined the role of p21 and p27 pathways using 

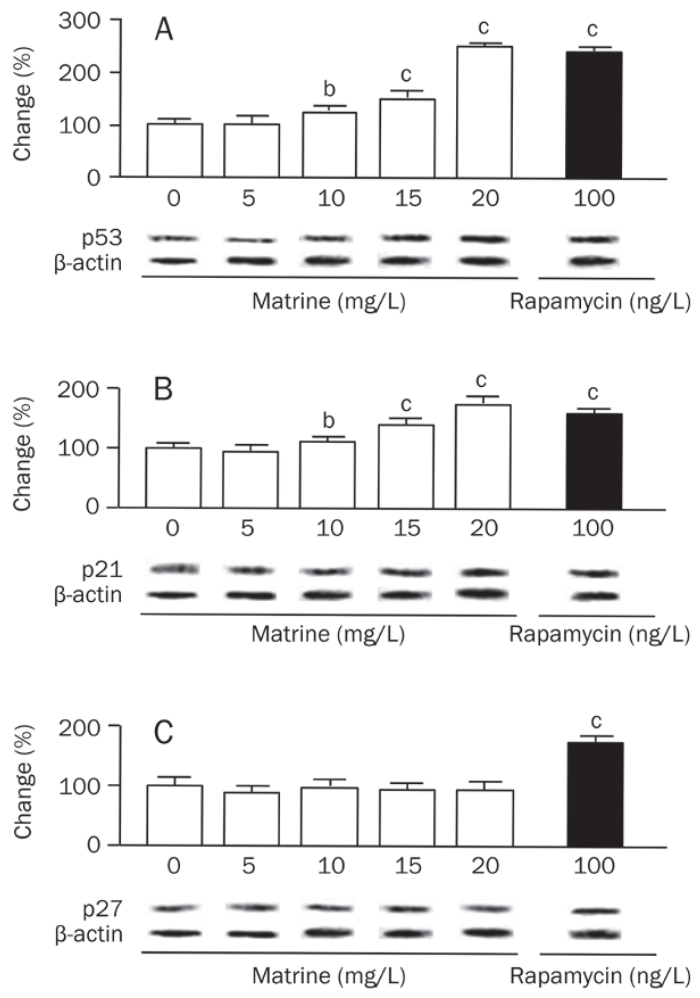

Figure 3. Effect of matrine on the expression of p53, p21, and p27 proteins in cultured VSMCs examined with Western blot. The levels of cell cycle-related proteins in cultured rat aortic VSMCs were investigated after treatments with various doses of matrine $(0,5,10,15$, and $20 \mathrm{mg} /$ L) for $72 \mathrm{~h}$. Rapamycin (100 ng/L) was as a positive control. (A) p53; (B) p21; (C) p27. Results were normalized by the respective level of $\beta$-actin. The changes in percentage of treatment control $(0 \mathrm{mg} / \mathrm{L}$ matrine) were calculated. Data are expressed as mean \pm SEM. $n=5 /$ group, One-way ANOVA. ${ }^{\mathrm{b}} P<0.05,{ }^{\mathrm{c}} P<0.01$ vs treatment control.

siRNA knockdown to decrease p21 and p27 expression. We found that matrine dose-dependently up-regulated p53 and p21 expression in VSMCs, but it did not affect the expression of $27^{[15,28]}$. SiRNA transfection targeting p21 abolished the inhibitory effect of matrine on VSMC proliferation, whereas, down-regulation of p27 had no influence on matrine's effect. Expression of p21 can be regulated by both p53 dependent and independent mechanisms ${ }^{[30-32]}$. In this study, we found that matrine treatment lead to increased p21 protein levels along with increased p53 levels in VSMCs. Therefore, the effect of matrine on 21 expression in VSMCs could be downstream of p53/p21 signaling. As mentioned previously, matrine has effects on multiple cellular functions, including anti-infection, anti-inflammation, anti-cancer activities. Matrine's anti-proliferative effect on VSMCs deserves further attention.

Mitogen stimulated cell cycle progression in mammalian cells requires the expression and activation of cyclin and cdk complexes ${ }^{[33]}$. These events are initiated by induction of cyclin D1, followed by induction of cyclin E, activation of cdk 4 and $\mathrm{cdk} 2$, and phosphorylation of $\mathrm{Rb}$ gene products. Mitogenic activation of cyclin D1/cdk4 and cyclin $\mathrm{E} / \mathrm{cdk} 2$ during $\mathrm{G}_{1}$
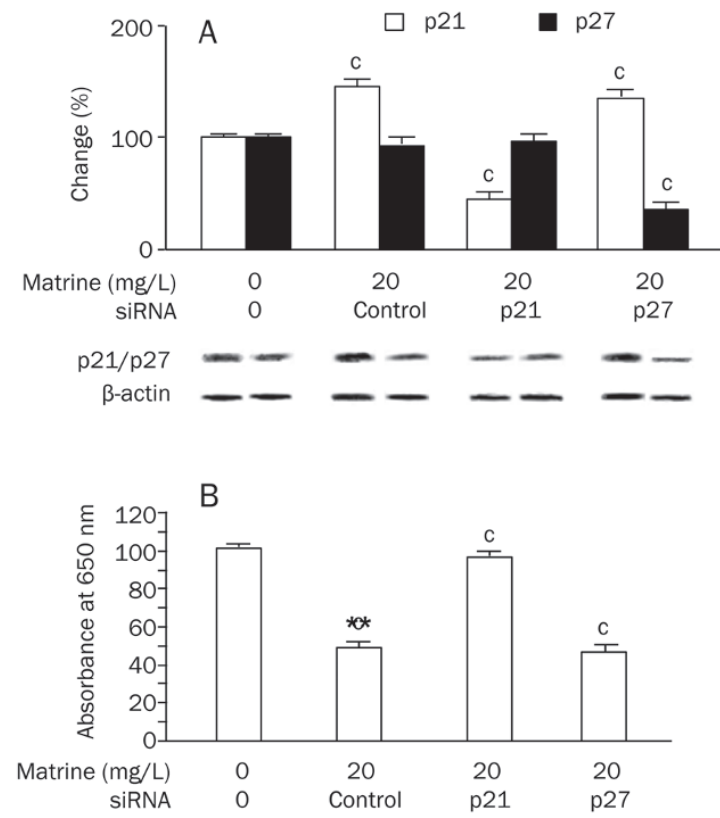

Figure 4. Role of p21 and p27 pathways in the inhibitory effect of matrine on VSMC proliferation. (A) siRNA treatment on p21 and p27 expression. Expression of p21 or p27 proteins in cultured rat aortic VSMCs were determined by Western blot after siRNAs transfection followed by matrine $(20 \mathrm{mg} / \mathrm{L})$ treatment for $72 \mathrm{~h}$. Results were normalized by the respective level of $\beta$-actin. The changes in percentage of basal $(0 \mathrm{mg} / \mathrm{L}$ matrine and $0 \mathrm{ng}$ siRNA) were calculated; (B) Effect of silencing p21 or p27 on matrine's anti-proliferative effect on cultured VSMCs. Cell growth was determined by colorimetric assay of methylene blue incorporation after respective siRNAs transfection followed with matrine $(20 \mathrm{mg} / \mathrm{L})$ for 72 h. The changes in percentage of basal $(0 \mathrm{mg} / \mathrm{L}$ matrine and $0 \mathrm{ng}$ siRNA) were calculated. Data are expressed as mean \pm SEM. $n=5 /$ group, twoway ANOVA. ${ }^{\circ} P<0.01$ vs basal or treatment control (siRNA control).

results in phosphorylation of the $\mathrm{Rb}$ protein ${ }^{[34]}$. Phosphorylated $\mathrm{Rb}$ functions as a gatekeeper for the $\mathrm{G}_{1}-\mathrm{S}$ transition by binding and sequestering E2F, a transcription factor that induces the expression of a battery of genes that are necessary for $S$ phase (DNA synthesis). In its unphosphorylated state, $\mathrm{Rb}$ binds and sequesters $\mathrm{E} 2 \mathrm{~F}$ to prevent transcriptional activation of target genes. In this study, we found that matrine decreased levels of cylin D1, cyclinE, cdk2, cdk4 and phosphorylated $\mathrm{Rb}$ in VSMCs in a pronounced manner. These findings are similar to findings from positive controls (rapamycin) and are consistent with previous reports ${ }^{[17]}$, including a study showing that up-regulation of cyclin $\mathrm{E}$ is absolutely required for cell cycle progression in VSMCs cultured in $10 \% \mathrm{FBS}^{[22]}$. Since $\mathrm{p} 53 / \mathrm{p} 21$ is a negative regulator of cyclins and $\mathrm{cdks}^{[35]}$, our data showing that matrine decreases cyclin D1 and E levels indicate that p53 and p21 may act downstream of matrine to affect cyclins and cdks. P27 is also a negative regulator that inhibits cyclins/cdks and $\mathrm{Rb}$ phosphorylation, and consequently results in $\mathrm{G}_{1}$ arrest ${ }^{[36]}$. Since p27 level did not change following matrine treatment, we do not expect that p27 participate in matrine's anti-proliferative effect in VSMCs. 

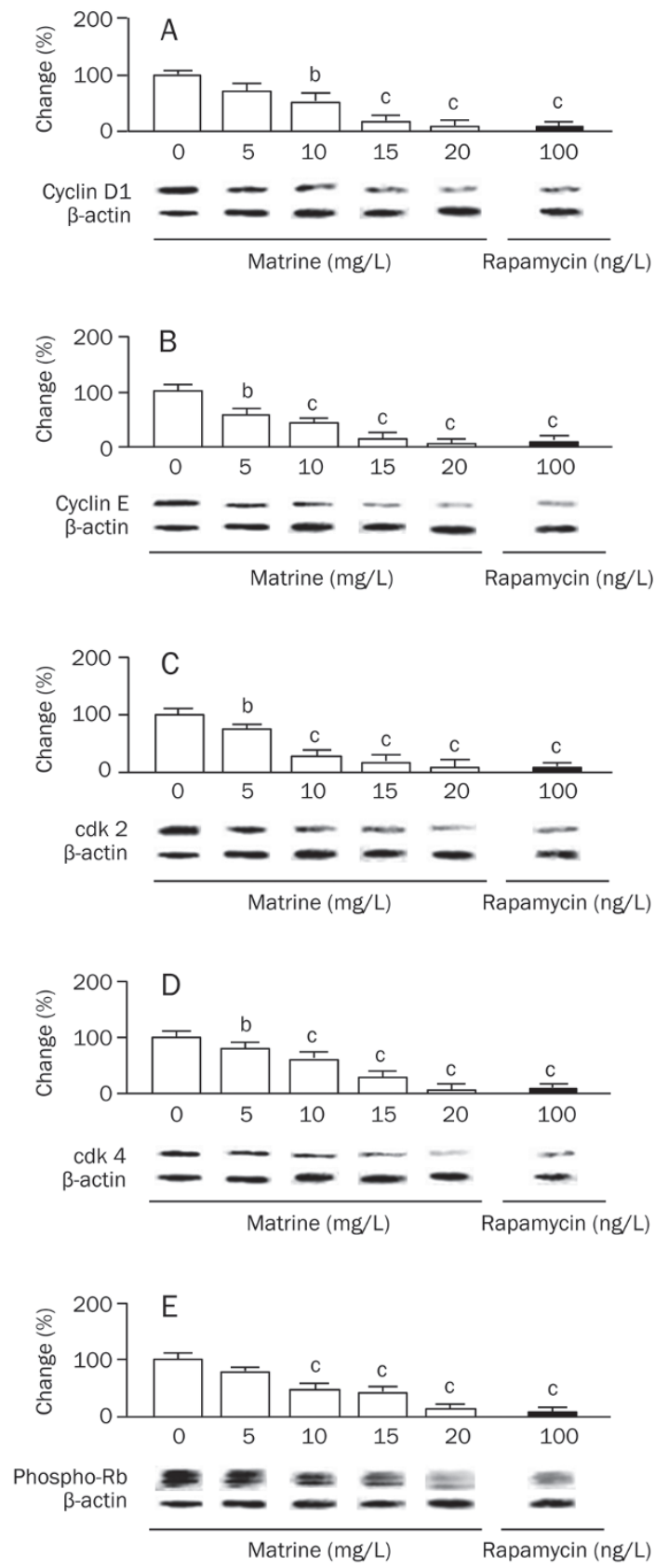

Figure 5. Effect of matrine on the expression of cell cycle regulating proteins in cultured VSMCs examined with Western blot. The levels of cell cycle-related proteins in cultured rat aortic VSMCs were investigated after treatment with various doses of matrine $(0,5,10,15$ and $20 \mathrm{mg} / \mathrm{L})$ for $72 \mathrm{~h}$. Rapamycin (100 ng/L) was as a positive control. (A) cyclin D1; (B) cyclin E; (C) cdk2; (D) cdk4; (E) Phos-Rb. Results were normalized by the respective level of $\beta$-actin. The changes in percentage of treatment control ( $0 \mathrm{mg} / \mathrm{L}$ matrine) were calculated. Data are expressed as mean \pm SEM. $n=5$ /group, One-way ANOVA. ${ }^{\mathrm{b}} P<0.05,{ }^{\mathrm{c}} P<0.01$ vs treatment control.

In summary, we demonstrated that matrine was a potent inhibitor of VSMC proliferation. Matrine leads to increases in p53 and p21 protein levels, and decreases in cdk2, cdk4, cyclin
D1, and cyclin E protein levels. However, whether matrine inhibits intimal hyperplasia must still be investigated in in vivo. Additionally, our data do not exclude the possibility that the matrine may exert its effects on VSMCs via affecting other cell cycle proteins such as E2F-1 ${ }^{[37]}$, or other mechanisms that regulate VSMC proliferation.

\section{Acknowledgements}

This work was supported by the Major International (Regional) Joint Research Project (2008DFA31140, PZ) and American Diabetes Association (1-10-BS-25, YC). We thank Ms Cathy Graham in the Biomedical PhD Program at Wright State University for her kind help in proof-reading this manuscript.

\section{Author contribution}

Ping ZHU, Yan-fang CHEN, and Jian ZHUANG designed research; Ping ZHU, Cheng ZHANG, Shao-yi ZHENG, Zhiling ZHOU, Rui-xin FAN, and Xiao-ping FAN performed research; Shu-zhen CHEN and Ji CHEN contributed new analytical tools and reagents; Ping ZHU, Ji-mei CHEN, and Guang LONG analyzed data; Ping ZHU, Yan-fang CHEN, and Jian ZHUANG wrote the paper.

\section{References}

1 Welt FG, Rogers C. Inflammation and restenosis in the stent era. Arterioscler Thromb Vasc Biol 2002; 22: 1769-76.

2 Ross R. The pathogenesis of atherosclerosis: a perspective for the 1990s. Nature 1993; 362: 801-9.

3 Zhou Y, Shan H, Qiao G, Sui X, Lu Y, Yang B. Inotropic effects and mechanisms of matrine, a main alkaloid from Sophora flavescens AIT. Biol Pharm Bull 2008; 31: 2057-62.

$4 \mathrm{Li} \mathrm{Y}$, Wang B, Zhou C, Bi Y. Matrine induces apoptosis in angiotensin II-stimulated hyperplasia of cardiac fibroblasts: effects on Bcl-2/Bax expression and caspase-3 activation. Basic Clin Pharmacol Toxicol 2007; 101: 1-8.

5 Li Y, Yang Y, Fang L, Zhang Z, Jin J, Zhang K. Anti-hepatitis activities in the broth of Ganoderma lucidum supplemented with a Chinese herbal medicine. Am J Chin Med 2006; 34: 341-9.

6 Ma L, Wen S, Zhan Y, He Y, Liu X, Jiang J. Anticancer effects of the Chinese medicine matrine on murine hepatocellular carcinoma cells. Planta Med 2008; 74: 245-51.

7 Liu XS, Jiang J. Molecular mechanism of matrine-induced apoptosis in leukemia K562 cells. Am J Chin Med 2006; 34: 1095-103.

8 Zhang $\mathrm{L}$, Wang $\mathrm{T}$, Wen $\mathrm{X}$, Wei $\mathrm{Y}$, Peng $\mathrm{X}$, Li H, et al. Effect of matrine on HeLa cell adhesion and migration. Eur J Pharmacol 2007; 563: 69-76.

9 Dai ZJ, Gao J, Ji ZZ, Wang XJ, Ren HT, Liu XX, et al. Matrine induces apoptosis in gastric carcinoma cells via alteration of Fas/FasL and activation of caspase-3. J Ethnopharmacol 2009; 123: 91-6.

10 Zhu MY, Jiang ZH, Lu YW, Guo Y, Gan JJ. Matrine and anti-tumor drugs in inhibiting the growth of human lung cancer cell line. Zhong Xi Yi Jie He Xue Bao 2008; 6: 163-5.

11 Zhang LP, Jiang JK, Tam JW, Zhang Y, Liu XS, Xu XR, et al. Effects of matrine on proliferation and differentiation in K-562 cells. Leuk Res 2001; 25: 793-800.

12 Jiang $\mathrm{H}$, Hou $\mathrm{C}$, Zhang $\mathrm{S}$, Xie H, Zhou W, Jin Q, et al. Matrine upregulates the cell cycle protein E2F-1 and triggers apoptosis via the mitochondrial pathway in K562 cells. Eur J Pharmacol 2007; 559: 
98-108.

13 Sinauridze El, Kireev DA, Popenko NY, Pichugin AV, Panteleev MA, Krymskaya OV, et al. Platelet microparticle membranes have 50- to 100 -fold higher specific procoagulant activity than activated platelets. Thromb Haemost 2007; 97: 425-34.

14 Wei JW, Liao JF, Chuang CY, Chen CF, Han PW. Cardiovascular effects of matrine isolated from the Chinese herb Shan-dou-gen. Proc Natl Sci Counc Repub China B 1985; 9: 215-9.

15 Fouty BW, Rodman DM. Mevastatin can cause $G_{1}$ arrest and induce apoptosis in pulmonary artery smooth muscle cells through a p27Kip1-independent pathway. Circ Res 2003; 92: 501-9.

16 Rao S, Porter DC, Chen X, Herliczek T, Lowe M, Keyomarsi K. Lovastatin-mediated $\mathrm{G}_{1}$ arrest is through inhibition of the proteasome, independent of hydroxymethyl glutaryl-CoA reductase. Proc Natl Acad Sci USA 1999; 96: 7797-802.

17 Braun-Dullaeus RC, Mann MJ, Seay U, Zhang L, von Der Leyen HE, Morris RE, et al. Cell cycle protein expression in vascular smooth muscle cells in vitro and in vivo is regulated through phosphatidylinositol 3-kinase and mammalian target of rapamycin. Arterioscler Thromb Vasc Biol 2001; 21: 1152-8.

18 Adams PD. Regulation of the retinoblastoma tumor suppressor protein by cyclin/cdks. Biochim Biophys Acta 2001; 1471: M123-M133.

19 Ekholm SV, Reed SI. Regulation of G(1) cyclin-dependent kinases in the mammalian cell cycle. Curr Opin Cell Biol 2000; 12: 676-84.

20 Aleem E, Kiyokawa H, Kaldis P. Cdc2-cyclin E complexes regulate the $\mathrm{G}_{1} / \mathrm{S}$ phase transition. Nat Cell Biol 2005; 7: 831-6.

21 Stacey DW. Cyclin D1 serves as a cell cycle regulatory switch in actively proliferating cells. Curr Opin Cell Biol 2003; 15: 158-63.

22 Geng Y, Yu Q, Sicinska E, Das M, Schneider JE, Bhattacharya S, et al. Cyclin E ablation in the mouse. Cell 2003; 114: 431-43.

23 Corsini A, Verri D, Raiteri M, Quarato P, Paoletti R, Fumagalli R. Effects of 26-aminocholesterol, 27-hydroxycholesterol, and 25-hydroxycholesterol on proliferation and cholesterol homeostasis in arterial myocytes. Arterioscler Thromb Vasc Biol 1995; 15: 420-8.

24 Thyberg J, Palmberg L, Nilsson J, Ksiazek T, Sjolund M. Phenotype modulation in primary cultures of arterial smooth muscle cells. On the role of platelet-derived growth factor. Differentiation 1983; 25 : 156-67.

25 Moses JW, Leon MB, Popma JJ, Fitzgerald PJ, Holmes DR, O'Shaughnessy C, et al. Sirolimus-eluting stents versus standard stents in patients with stenosis in a native coronary artery. N Engl J Med 2003; 349: 1315-23.

26 Schofer J, Schluter M, Gershlick AH, Wijns W, Garcia E, Schampaert $\mathrm{E}$, et al. Sirolimus-eluting stents for treatment of patients with long atherosclerotic lesions in small coronary arteries: double-blind, randomised controlled trial (E-SIRIUS). Lancet 2003; 362: 1093-9.

27 Oliver MH, Harrison NK, Bishop JE, Cole PJ, Laurent GJ. A rapid and convenient assay for counting cells cultured in microwell plates: application for assessment of growth factors. J Cell Sci 1989; 92 (Pt 3): 513-8.

28 Ferri N, Granata A, Pirola C, Torti F, Pfister PJ, Dorent R, et al. Fluvastatin synergistically improves the antiproliferative effect of everolimus on rat smooth muscle cells by altering $\mathrm{p} 27 \mathrm{Kip} 1 /$ cyclin $\mathrm{E}$ expression. Mol Pharmacol 2008; 74: 144-53.

29 Endesfelder S, Kliche A, Lochmuller H, von MA, Speer A. Antisense oligonucleotides and short interfering RNAs silencing the cyclindependent kinase inhibitor p21 improve proliferation of Duchenne muscular dystrophy patients' primary skeletal myoblasts. J Mol Med 2005; 83: 64-71.

30 Macleod KF, Sherry N, Hannon G, Beach D, Tokino T, Kinzler K, et al. p53-dependent and independent expression of p21 during cell growth, differentiation, and DNA damage. Genes Dev 1995; 9: 93544.

31 Takahashi A, Taniguchi T, Ishikawa Y, Yokoyama M. Tranilast inhibits vascular smooth muscle cell growth and intimal hyperplasia by induction of p21(waf1/cip1/sdi1) and p53. Circ Res 1999; 84: 54350.

32 Dulic V, Kaufmann WK, Wilson SJ, TIsty TD, Lees E, Harper JW, et al. p53-dependent inhibition of cyclin-dependent kinase activities in human fibroblasts during radiation-induced $\mathrm{G}_{1}$ arrest. Cell 1994; 76 : 1013-23.

33 Sherr CJ. Cancer cell cycles. Science 1996; 274: 1672-7.

34 Morgan DO. Principles of CDK regulation. Nature 1995; 374: 131-4.

35 Xiong Y, Hannon GJ, Zhang H, Casso D, Kobayashi R, Beach D. p21 is a universal inhibitor of cyclin kinases. Nature 1993; 366: 701-4.

36 Toyoshima H, Hunter T. p27, a novel inhibitor of G1 cyclin-Cdk protein kinase activity, is related to p21. Cell 1994; 78: 67-74.

37 Jiang $\mathrm{H}$, Hou C, Zhang S, Xie H, Zhou W, Jin Q, et al. Matrine upregulates the cell cycle protein E2F-1 and triggers apoptosis via the mitochondrial pathway in K562 cells. Eur J Pharmacol 2007; 559: 98-108. 